\title{
DIREITO DO TRABALHO E DIREITO DOS CONTRATOS: APONTAMENTOS RELEVANTES SOBRE A PARTE ESPECIAL DO NOVO CÓDIGO CIVIL (LEI N. 10.406, de 10.01.2002)
}

\author{
Guilherme Guimarães Feliciano \\ Doutorando pela Faculdade de Direito da \\ Universidade de São Paulo
}

Resumo:

As inovações do Novo Código Civil em relação ao Direito do Trabalho, com ênfase aos dispositivos da Parte Especial do Novo Código Civil.

Abstract:

The innovations of the New Civil Code related to the Labor Law, emphasing the Special Part features.

Unitermos: contratos no Direito do Trabalho; Novo Código Civil.

\section{Introdução.}

O presente trabalho propõe examinar, sem maiores digressões, o ensejo e a forma de aplicação das normas dispostas pela Lei n. 10.406/2002 ("Institui o Código Civil") ao Direito do Trabalho e, no geral, às relações sociais de trabalho - como também, indiretamente, ao próprio Direito Processual do Trabalho, por via reflexa. Como, todavia, não se pretende exaustivo, atém-se aos dispositivos da Parte Especial do Novo Código Civil (NCC), mais exatamente àqueles que, a partir do art. 421, tratam "Dos Contratos em Geral" no que convir e couber dizer.

Com esse propósito, o art. parte da teoria geral dos contratos, tal como posta pela Lei n. 10.406/2002, para ali identificar princípios e institutos úteis aos operadores do Direito do Trabalho, com especial atenção para as novidades introduzidas pelo novo Código.

Futuramente, deveremos pinçar, entre os vários contratos típicos do Código Civil de 2002, aqueles mais encontradiços no âmbito do processo do trabalho (nomeadamente, a doação, a prestação de serviços, a empreitada, o mandato, a transação e o compromisso), comentando-os brevemente e analisando-os à luz do novo regramento legal. 
Por ora, todavia, interessa destrinçar os aspectos mais relevantes da teoria geral. Passemos, pois, ao estudo da "lex nova"

II. Dos contratos em geral (Título V - arts. 421 a 480).

No estudo das aplicações da teoria geral dos contratos ao Direito do Trabalho, é curial recordar, em caráter propedêutico, a nota fundamental insculpida no art. 8", par. único, da CLT (que regeu a aplicabilidade do Direito Civil aos contratos de trabalho sob a égide do Código Civil de 1916 e continua a regê-la, agora sob o pálio do Código Civil de 2002): a subsidiariedade. Significa dizer que as normas de Direito Civil informam as relações de trabalho em caráter subsidiário, o que pressupõe o atendimento de duas condições de aferição estritamente hermenêutica, a saber, (1) a lacuna no sistema legal-trabalhista, e (2) a compatibilidade entre a norma de Direito Civil c os princípios retores do Direito do Trabalho (sintetizados em quatro entidades, na célebre partição de Plá Rodriguez' : princípio da proteção, princípio da primazia da realidade, princípio da irrenunciabilidade e princípio da razoabilidade).

Dizer que essas duas condições têm aferição estritamente hermenêutica significa reconhecer que, na prática, a identificação de lacunas e o juízo de compatibilidade são tarefas que geralmente exigem especiais esforços do intérprete, não raro alimentados pela sua predisposição ideológica (no sentido de transigir ou não com a norma exógena) e pelos seus vínculos culturais. Às questões de aplicação subsidiária do Direito Civil geralmente não se impõe o axioma "in claris cessat interpretatio" $æ$ máxima refutada, ademais, pela moderna teoria jurídica, para a qual não há norma jurídica que prescinda de interpretação. É compreensível, portanto, que juristas de diversas linhagens partam dos mesmos pressupostos (i.e., da mesma situação de fato e das mesmas fontes formais do direito) e concluam de modo diametralmente oposto, aqui pela aplicação subsidiária da norma civil e, ali, pela sua não-aplicação. É o que se tem visto, e.g., no campo do processo ( $u t$ art. 769 da CLT), após a edição da Lei n. 10.352 de 26.12.2001, que deu redação ao parágrafo 2 " ao art. 475 do $\mathrm{CPC}^{2}$ : enquanto muitos recusam sua aplicação ao processo do trabalho, por

1. Américo Plá Rodriguez, Princípios de Direito do Trabalho, trad. Wagner Giglio, 4a tiragem, São Paulo, LTr, 1996, passim.

2. “Não se aplica o disposto neste art. [reexame necessário] sempre que a condenação, ou o direito controvertido, for de valor certo não excedente a 60 (sessenta) salários mínimos, bern como no caso de procedência dos embargos do devedor na execução de dívida ativa do mesmo valor" 
entenderem não haver lacuna, outros pugnam pela aplicação, ao argumento de que a lacuna é óbvia ${ }^{3}$...

Na teoria geral dos contratos, não será diferente. Por isso, manda a cautela que iniciemos o estudo pelos aspectos menos movediços, à vista do que já prevalecia à luz do Código Civil de 1916.

\subsection{Formação do contrato e autonomia de vontades.}

O art. 421 do NCC estabelece que a liberdade de contratar será exercida em razão e nos limites da função social do contrato. Ao reconhecer, nesse sentido, uma função aos contratos em geral, o legislador repudia a idéia liberal de que todo acordo de vontades é válido, desde que reúna partes capazes em torno de um objeto lícito e determinado (ou determinável): a atividade de contratar não é livre desse modo, porque a ela se contrapõe a função social dos contratos, que o Estado resguarda como "atividade finalisticamente dirigida à tutela de interesse de outrem, caracterizando-se pela relevância global, homogeneidade de regime e manifestação através de um deverpoder"4

A função social do contrato determina, portanto, os limites da liberdade de contratar. Nessa ensancha, Nery Jr. e Andrade Nery reconhecem, no preceito (art. 421 do NCC), três cláusulas gerais (Generalklausen) do direito dos contratos, ditas

3. Cfr., e.g., José Antonio Ribeiro de Oliveira Silva (A alteraģão nos arts. 475 e 515 do CPC e stua aplicação no processo do trabalho, in Revista LTr 66-12/146I-1468): "Nenhuma objeção séria pode haver quanto à subsidiariedade de tal norma no processo do trabal ho, porquanto previstos os dois requisitos para tanto: a lacuna do Decreto-lei $n$. 779/69 e a perfeita compatibilidade com os princípios do referido processo (art. 769 da CLT)" (p. 1.463). Menos categórico, Manoel Antonio Teixeira Filho (Código de Processo Civil æalteraçöes: breves comtentários às Leis ns. 10.352 e 10.358/200I, in Revista LTr 66-03/ 263-276) observou que a primeira parte do parágrafo 2o do art. 475 do CPC poderia ser aplicada ao processo do trabalho (p. 264). E, ein sentido contrário, Bruno Fernandes Albuquerque (A última reforma do Código de Processo Civil e a sua repercussão no processo do trabalho, in Revista LTr 66-03/300309): "Quanto à limitação eın 60 (sessenta) salários imposta pelo parágrafo segundo do art. 475 do CPC, haverá quem defenda a sua aplicação ao processo do trabalho [...]. Entretanto, entendemos que o legislador ao criar tal valor referencial para envio ou não ao tribunal ad quem da decisão contrária a Fazenda Pública, tornou disponíveis, apenas para o processo civil, as condenaçôes iguais ou inferiores a 60 (sessenta) salários mínimos. Isto porque a norma deve ser interpretada de forma restritiva, já que fere a regra constitucional da indisponibilidade dos recursos Públicos e o princípio da legalidade na administração pública" (pp. 304-305 - g.n.). De nossa parte, acompanhamos esse último escólio (pela não-aplicabilidade): embora possa não ser a solução mais útil para a grande ınassa de jurisdicionados, é a mais técnica à mercê do sistema jurídico vigente, já que o Decreto-lei $779 / 69$ regulou inteiramente os efeitos do processo do trabalho em relação aos entes da Adıninistração Pública.

4. Cfr., mutatis mutandi, Antonio Herman V. Benjaınin, Função Ambiental, in Dano Ambiental Prevenção, Reparação e Repressão, São Paulo, Revista dos Tribunais, 1993, p.28. 
tais as "normas orientadoras sob forma de diretrizes, dirigidas principalmente ao juiz, vinculando-o ao mesmo tempo em que lhe dão liberdade para decidir": a autonomia privada (= liberdade de contratar), o respeito à ordem pública e a função social do contrato, que interagem entre $\mathrm{si}^{\mathrm{s}}$

A rigor, a função social do contrato $\mathfrak{x}$ aquilo que, nos contratos, destinase ao interesse alheio, com a nota da relevância global (caráter publicístico) e a natureza de poder-dever, sob regime homogêneo $æ$ é a de propiciar circulação de riqueza, transferindo-a de um patrimônio a outro' ${ }^{6}$ No Direito do Trabalho, permite-se reconhecer, para além disso, as funções sociais de distribuição de riqueza (obstando, na ótica marxista, uma apropriação selvagem e desumana da mais-valia) e de tutela da dignidade humana (a relação de trabalho $\mathfrak{x}$ de perfil contratual-institucional $\mathfrak{x}$ surge no horizonte histórico como instrumento jurídico de salvaguarda mínima dos interesses econômicos e psicossomáticos do trabalhador, desaguando na diç̧ão doutrinal do princípio da proteção), desempenhadas pelo contrato de trabalho, a teor dos art. s 1", III e IV, 3", I e III, e 170 da CRFB/88.

Reconhecer tais funções sociais, que são inerentes ao contrato de trabalho e admitem fácil cognição a partir da interpretação histórico-teleológica dos arts. $2^{\circ}, 3^{\circ}$ e 442, caput, da CLT (ou à mercê de interpretação sistemática que tome em consideração o art. $5^{\circ}$ do Decreto-lei n. 4.657/42 æ Lei de Introdução ao Código Civil æ, pelo qual a lei se aplica com vistas aos seus fins sociais e às exigências do bem comum), importa em carrear, para o juiz do Trabalho, o poder de intervenção corretiva nos contratos de trabalho, ajustando suas cláusulas, expressas e/ou tácitas, às suas funções sociais proeminentes". Isso porque, "como a função social é cláusula geral, o juiz poderá preencher os claros do que significa 'função social' com valores jurídicos, sociais, econômicos e morais. A solução será dada diante do que se apresentar, no caso concreto, ao juiz. Poderá proclamar a inexistência do contrato por falta de objeto; declarar sua nulidade por fraude à lei imperativa (CC 166 VI),

5. Nelson Nery Junior, Rosa Maria de Andrade Nery, Now Código Civil e Legislaçăo Extravagante Anotados, São Paulo, Revista dos Tribunais, 2002, pp. 06 (citando Franz Wieacker) e 180-181.

6. Idem, p. 181 (citando Enzo Roppo).

7. Nesse sentido, reconhecendo o poder de intervenção corretiva do juiz do Trabalho no marco dos contratos individuais de trabalho, cfr. Mozart Victor Russomano, Princípios Gerais de Direito Sindical, Rio de Janeiro, Forense, 1995, pp.232-233 (narrando caso em que, ainda juiz, apreciou reclaınatória trabalhista na qual um vigia noturno reclamava a alteração das condições do contrato de trabalho, por sofrer de dores reumáticas e estar submetido ao frio e à umidade da noite, já que o empregador não construíra guarita). 
porque a norma do CC 421 é de ordem pública (CC 2035 par. ún. ); convalidar o contrato anulável (CC 171 e 172); determinar a indenização da parte que desatendeu a função social do contrato etc. São múltiplas as possibilidades que se oferecem como soluções ao problema do desatendimento à cláusula geral da função social do contrato" No mesmo diapasão, o juiz do Trabalho também pode proclamar a incxistência de contrato de trabalho por falta de objeto, nas simulações concertadas para fraudar a Previdência Social, ainda se houver anotação em CTPS; do mesmo modo, pode declarar a nulidade do contrato de trabalho por violação à norma imperativa do art. 37, II, da CRFB (limite de ordem pública), embora reconheça o direito aos salários æ Enunciado n. 363 do C.TST æou até a mais do que isso" Pode, enfïm, invalidar cláusulas contratuais que comprometam a função social do contrato de trabalho, ainda que essenciais àquele contrato æ como se dá, amiúde, nos contratos de adesão de trabalhadores subordinados às cooperativas de mão-deobra que mercadejam força de trabalho, nos quais as partes "concordam" tratar-se de vínculo cooperativo, sob o manto do art. 442, par. único, da CLT (mesmo porque, nesses casos, a aposição da cláusula tende a configurar simulação, dolo ou coação "in contrahendo") ${ }^{16}$

O art. 421 do NCC dispõe, ainda, que a autonomia privada $a$ que também é, por si mesma, emanação do princípio constitucional da dignidade humana (art. I", III, da CRFB) æ tem, na função social do contrato, não apenas um limite, mas também um foco: deve ser exercida em razão dessa última. Dão-se, aí, ensejo e parâmetro legal-positivo para a operação do princípio da razoabilidade no Direito do Trabalho, com maior precisão e segurança, relegando a planos secundários focos nebulosos como a "compreensão intuitiva da razoabilidade" (Holmes) ou a própria lógica cartesiana,

8. Idem, ibidem (g.n.).

9. Cfr., e.g., TRT/SP-15a Reg., 12.797/96, Ac. SE 19.686/97, rel. Edison Laércio de Oliveira, in D.O.E. 04.08.1997, p.128; TRT/CE-7a Reg., REO 2.359/0।, Ac. 3.259/0I, rel. Laís Mira Rossas Freira, in DOJT 27.09.200I. Releva transcrever, desse último, a passagem seguinte: “( ...) a nulidade, no entanto, tem efétos ex munc, face à teoria do contrato realidade, garantindo-se à obreira não somente os salários, mas os demais direitos trabalhistas (...)". Pensamos, tambémn nós, desse modo.

10. Cfr., por todos, TRT/SC-12aReg., RO-EV 02107-2001-003-12-00-5, Ac. 3a T. 13889/02, 05.11 .2002 , rel. Gisele Pereira Alexandrino, in DJSC 1I.12.2002, p.138 (reconhecendo vínculo empregatício entre o trabalhador e a cooperativa à qual aderiu, pois "inexiste a possibilidade de reconhecimento de vínculo de emprego diretamente com o Município (art. 37, Il, da CF)" æ que, todavia, foi condenado a responder pelos créditos trabalhistas em caráter subsidiário). Dolo, no texto principal, têm a acepção civilista de indução a erro. 
estruturalmente impassível e aética" ${ }^{11}$. A norma em comento privilegia, ao revés, a lógica social do contrato, compensando, com um critério sociológico (plástico, mas objetivo), a "certa dose de subjetividade" que informa o princípio ${ }^{12}$

O preceito em questão também encerra utilidade para os supostos de Direito Coletivo do Trabalho. Mesmo nesse campo, a autonomia privada $\mathfrak{x}$ dita autonomia coletiva de vontades $\mathfrak{x}$ limita-se pelo respeito à ordem pública e pela função social do contrato. Esse entendimento franqueia a possibilidade de anulação judicial de cláusulas convencionais negociadas de modo abusivo ou sob situação de desequilíbrio, como contrapartida jurisdicional à ação de sindicatos fracos e "pelegos" e sem violação direta à norma do art. $7^{\circ}, \mathrm{XXVI}$, da CRFB. Terá especial relevância ao cnsejo da reforma do art. 618 da CLT, caso consume-se como alvitrada pela pasta do Trabalho ao apagar das luzes do último governo, i.e., com a malsinada "flexibilização" dos direitos trabalhistas, ressalvadas as disposições constitucionais e as normas de saúde e segurança do trabalho. É que, à luz do art. 421 do NCC, serão nulas não apenas as cláusulas que desrespeitarem direitos trabalhistas constitucionais, lei complementar, legislação tributária, previdenciária e de FGTS, mas também aquelas em que a liberdade de contratar esteja comprometida ou seja exercida sem respeito à função social dos contratos coletivos, por vício "in contrahendo" (art. 2035 par. único). Abre-se, pois, uma via adicional de tutela jurídica dos interesses coletivos, ao alcance da primeira instância a mesmo à mercê de um sistema legal-trabalhista "flexibilizado"

\subsection{Princípios da probidade e da boa-fé na conclusão e execução dos contratos.}

$\mathrm{O}$ art. 422 do NCC estabelece que os contratantes são obrigados a guardar, assim na conclusão do contrato, como em sua execução, os princípios da probidade e da boa-fé. Comentando o preceito, Nery Jr. pondera que "ao intérprete (...) incumbe a exegese do negócio jurídico em consonância com a principiologia do sistema"13.

11. Cfr. Aınérico Plá Rodriguez, op.cit., p.251: "Reduzido (...) podemos dizer que o princípio da razoubilidade consiste na afirmação essencial de que o ser humano, em suas relações trabalhistas, procede e deve proceder conforme à razäo" Adiante, exemplifica coon a "racionalidade da subcontratascāo": há gen':íno contrato de trabalho autônomo se, do ponto de vista racional, justifica-se o trabalho autônomo pela índole da atividade encomendada. Confundem-se, èn últiına instância, razoabilidade e racionalidade (cın acepção cartesiana). Com a ótica ditada pelo art. 421 do NCC c.c. art. 8o, par. único, da CLT, dir-se-á que a subcontratação deve se justificar não apenas pela racionalidade econômica do negócio, mas tambéın pela função social desse contrato, em cuja razão e sob cujos limites deve ser exercida a liberdade de contratar.

12. Idem, p.256.

13 Op.cit., p.422. 
Cumpre reconhecer, nesse passo, um princípio de boa-fé subjetiva (que equivale à ineficácia da reserva mental - art. 110 do NCC), ao lado de um princípio da boa-fé objetiva (relativo às legítimas expectativas de direito engendradas pelas circunstâncias objetivas e incutidas no "bonus pater familiae") e do próprio princípio da aparência (pelo qual a "aparência de direito produz os mesmos efeitos da realidade de dircito, salvo particulares restrições legais"'14), ambos dimanados do art. em comento.

No Direito do Trabalho, a utilidade desses princípios - os dois primeiros positivados e o último implícito à norma do art. 422 cstá na fiscalização judicial do modo de execução dos contratos coletivos (acordos coletivos de trabalho e convenções coletivas de trabalho), tanto mais pronunciada se vingar a polêmica reforma do art. 618 da CLT. Está, ainda, na base da solução de problemas específicos de direito individual do trabalho, como (1) a responsabilidade do futuro empregador pela promessa de contratar elou pelas cláusulas de pré-contrato de trabalho (princípio da boa-fé objetiva - vide arts. $427^{15}$ e 463 do NCC) e (2) a responsabilidade do empregador público pelos consectários de contrato de trabalho nulo ( $C F$ art. $\left.37, \$ 2^{\circ}\right)$, em casos de cooptação do trabalhador de boa-fé mediante contrato aparentemente válido e eficaz (princípio da aparência - cfr., supra, nota n. 9).

Aplicando o princípio da boa-fé objetiva em circunstâncias semelhantes (relação de assimetria contratual estabelecida com hipossuficiente econômico), o Superior Tribunal de Justiça houve por bem garantir a um mutuário, constrito por dívida com instituição bancária, a suspensão da execução judicial do crédito, por ter o réu se apresentado espontaneamente para o acerto de contas, fiando-se em compromisso público assumido pelo então ministro da Fazenda mediante "memorando de entendimento" (que prometia aquela suspensão, desde que houvesse apresentação espontânea do devedor $\mathrm{c}$ atendimento às condiçõcs mínimas dispostas no texto), a que se deu ampla publicidade. Para assim decidir, o relator bascou-se no valor jurídico da justa expectativa, em vista do imperativo social de lealdade (= probidade) e do principio da boa-fé objetiva, expressamente referido na ementa (STJ, 4' T., RMS 6183, rel. min. Ruy Rosado de Aguiar, v.u., j. 14.11.1995'6).

14 Vicente Ráo, Ato Jurídico, 4a ed., São Paulo, Revista dos Tribunais, 1997, p. 210.

15 "A proposta do contrato obriga o proponente, se o contrário não resultar dos termos dela, da natıreza do negócio, ou das circunstâncias do caso" Correspondência: art. 1080 do Código Civil de 1916.

16 Apud Nery Jr., op.cit., p. 181. 
2.3. Cláusulas leoninas.

O Código Civil, de 2002, contempla a regra de que, "nos contratos de adesão, são nulas as cláusulas que estipulem a renúncia antecipada do aderente a direito resultante da natureza do negócio" (g.n.). O preceito empresta positividade à vedação de certa modalidade de cláusula leonina muito comum no dia-a-dia (sem prejuízo da possibilidade de intervenção judicial corretiva em contratos informados por pactos leoninos de diversa espécie, seja por conta das cláusulas gerais e dos princípios acima reportados função social do contrato, ordem pública, probidade, boa-fé objetiva -, seja ainda em virtude da própria natureza sinalagmática dos contratos em geral).

No Direito do Trabalho, identificam-se concretamente três casos-tipos em que a utilidade da norma civil acima transcrita é realçada. A uma, serve para a declaração "in limine litis" da nulidade de cláusulas limitativas de responsabilidades nos contratos de trabalho (e.g., as renúncias prévias à dação de aviso prévio ou a indenizações por danos morais e/ou materiais); pode-se chegar à mesma solução, todavia, aplicando o clássico princípio da irrenunciabilidade ou o próprio art. 9" da CLT. Serve, a duas, para a declaração "in limine litis" (i.e., independentemente de instrução processual) da nulidade de cláusulas de contratos-formulários que, na prestação de serviços, excluem "ab ovo" a formação de vínculo de emprego (e.g., contratos de adesão a sociedades cooperativas, contratos de representação, contratos de empreitada e outras modalidades que usualmente "mascaram" autênticas relações empregatícias) $\mathfrak{x}$ e, nesses casos, a tese da irrenunciabilidade e da elisão de direitos nem sempre se acomoda, porque são usuais os argumentos de que, eximindo-se de encargos sociais, o trabalho "autônomo" era mais vantajoso ao trabalhador (enquanto as idéias de renúncia e elisão pressupõem, em tese e princípio, o prejuízo). Por outro lado, aplicando a regra em comento, o juiz do Trabalho basta-se na convicção de que o direito renunciado é inerente à natureza do negócio, sem cogitar da sua vantagem ou desvantagem para o trabalhador (cogitação que, não raro, exigiria a perícia contábil, dando azo a requerimentos que já se vêem formulados em processos desse jaez).

No mesmo diapasão, o C. STJ já decidiu que "somente nos casos ressalvados ou autorizados por lei se mostra admissível a limitação da responsabilidade" (STJ, 4: T., REsp 83717-MG, rel. Min. Sálvio de Figueiredo Teixeira, v.u., j. 12.12.1996 ${ }^{17}$ ) æ hipótese do art. 462, §1", da CLT (possibilidade legal de extensão

17. Idem, p. 182. 
contratual da responsabilidade do empregado nos danos culposos, com prejuízo da intangibilidade salarial).

\subsection{Contratos atípicos: legalidade geral.}

O Código Civil, de 2002, estabelece, ainda, um padrão geral de legalidade que referenda o prestígio liberal à autonomia privada $\mathfrak{x}$, nesse passo, reconhece validade apriorística a todos os contratos atípicos. Contratos atípicos são aqueles que não encontram subsunção estrita nas modalidades legalmente dispostas, ou que reúnem, em figura híbrida, características essenciais de dois ou mais contratos lípicos (rectius: legalmente descritos).

Essa regra de legalidade geral deve ganhar relevância no exercício da judicatura trabalhista, mormente se a Justiça do Trabalho for contemplada, nas reformas constitucionais que se anunciam (sob a inodora rubrica de "Reforma do Judiciário"), com a competência material para processar e julgar litígios decorrentes de qualquer relação de trabalho (aí incluído o trabalho subordinado $\mathfrak{x}$ empregados e avulsos $\mathfrak{x} \mathrm{e}$ trabalho não-subordinado, eventual e voluntário).

É que não são desconhecidas do mundo do trabalho hipóteses de contratos de trabalho ("lato sensu") genuinamente híbridos ou genericamente atípicos. Na Itália, conhece-se a figura da parassubordinação ${ }^{i k}$, em que há um vínculo contínuo de colaboração sem estrita subordinação (cirr. legge n. 2.049/99), com estatuto jurídico misto. É o caso, e.g., do chamado "teletrabalho", a cujo respeito já polemiza a doutrina nacional. No Brasil, merece referência a Lei 4.886/56, que chega a positivar o hibridismo, estendendo ao representante comercial autônomo figuras típicas da relação de emprego (pré-aviso, indenização por denúncia vazia do contrato, justo motivo para rescisão pelo representado e pelo representante etc. $\mathfrak{x}$ cfr. arts. 34 a 36).

Agora, com o novo estatuto civil e a sua aplicação subsidiária às relações de trabalho, caberá ao intérprete $æ$ e muito especialmente ao juiz do Trabalho, caso estendida a sua competência material para os conflitos de trabalho em geral a reconhecer, por principio, a liberdade das partes em firmarem contratos de trabalho ("lato sensu") atípicos, com estatutos jurídicos híbridos ou particulares. A validade desses contratos, bem como das cláusulas que os compõem, haverá de ser refutada apenas em caso de vícios sociais (fraude, simulação) ou de consentimento (erro, dolo, coação), cuja prova incumbe à parte interessada (art. 9" c.c. art. 818 da CLT).

18. Amauri Mascaro Nascimento, Conferência de Aberfura, in $10^{\circ}$ Congresso Brasileiro de Direito do Trabalho, São Paulo/SP, LTr, 16.04.2002. 
Por outro lado, haverá casos em que as próprias circunstâncias do trabalho são indiciárias da essencialidade dos direitos trabalhistas consolidados (assim, e.g., em todas as hipóteses de "marchandage" de trabalho subordinado). Nesses casos, a regra geral de legalidade dos contratos atípicos não resiste à principiologia peculiar do Direito do Trabalho (notadamente os princípios da primazia da realidade e da razoabilidade), de modo que, sob tais circunstâncias, impõc-se inverter o ônus da prova, exigindo da parte reclamada a prova da licitude do regime híbrido ou atípico. Conforme a hipólese, as cláusulas atípicas insinuarão renúncia antecipada de dircitos increntes à nalureza da relação jurídica, reclamando a aplicação da norma examinada no tópico 2.3 (supra).

2.5. Fato de terceiro e contrato preliminar de trabalho.

$\mathrm{O}$ art. 440 do NCC dispõe que "nenhuma obrigação haverá para quem se comprometer por outrem, se este, depois de se ter obrigado, faltar à obrigação" O preceito não tem correspondência no Código Civil, de 1916. Dele decorre que, se houver compromisso expresso ou tácito de terceiro para com o objeto da promessa, o ato mesmo de se obrigar, dimanado pelo terceiro, redimensiona os vínculos obrigacionais, carreando-lhe a responsabilidade integral por eventuais inadimplementos.

"A contrario", se o terceiro não se obrigar, a responsabilidade integral pela promessa de obrigação de terceiro circunscreve-se à esfera jurídica do promitente, ut art. 439, caput, do NCC.

No âmbito das relações de trabalho, a aplicação subsidiária desta norma é útil na medida em que enseja a partição das responsabilidades ínsitas às promessas de contratação por terceiros. Problemas dessa ordem apresentam-se, com certa lireqüência, nos expedientes de cooptação das agências de emprego $\mathfrak{x}$ sobretudo quando a cooptação revela-se fraudulcnta. Com cfeito, algumas empresas não sc limitam a agenciar o trabalhador desempregado, oferecendo-lhe, mediante pagamento, cursos c mélodos para reciclagem e aperleiçoamento, sob o pretexto de lacilitar o seu acesso ao mercado de trabalho. Sempre há nesse expediente, em alguma medida, o chamado "dolus bonus" Quando essas ofertas tornam-sc condif̧ão alegada para o emprego, aliando-se à promessa ou garantia do próprio emprego e à identificação precisa do futuro empregador (terceiro), configura-se o dolo (= indução a erro), se não houve a adesão do terceiro ao objeto da promessa. Adiante, frustrado o objeto, assiste ao cliente o direito de ressarcir-se por perdas e danos, na forma dos arts. 128 e 439 do NCC. 
A competência material para o processo e julgamento desse litígio, que versa sobre responsabilidade civil contratual, ć alecta à Justiça comum, nos termos do art. 114, caput, da CRFB/88 (desde que a promessa não assuma foros de pré-contrato de trabalho, com as especificidades do art. $462^{19}$ do NCC). Se, todavia, a promessa do fato de terceiro congrega todos os elementos típicos essenciais do contrato definitivo (i.e., do contrato de trabalho "stricto sensu"), houve contrato preliminar (pré-contrato) de trabalho, o que desloca a competência para a Justiça do Trabalho. Isso porque se entende, em boa doutrina, que a Justiça do Trabalho é competente para dirimir os dissídios entre trabalhadores e empregadores, em estado atual (contrato definitivo) ou potencial (contrato preliminar). É o que deflui do magistério de Wilson de Souza Campos Batalha $^{20}$ (com fundamento em Ernesto Krotoschin), das lições de Délio Maranhão¹ e, mais recentemente, de aresto do $C$. Tribunal Superior do Trabalho em que se reconheccu a competência da Justiça do Trabalho para o julgamento de ação de danos morais fundada em pré-contrato de trabalho.

Firmado o pré-contrato de trabalho a que, $\mathrm{cm}$ face do art. 442, caput, da CLT, poderá ser escrito ou verbal $\mathfrak{x}$ "qualquer das partes terá o direito de exigir a celebração do [contrato] definitivo, assinando prazo à outra para que o efetive" na diç̧ão do Código Civil de 2002. Se o cstipulante $\mathfrak{x}$ cmpresa ou trabalhador $\mathfrak{x}$ não der cxccução ao contrato preliminar, "poderá a outra parte considerá-lo desfeito, e pedir perdas e danos". Já era esse, como dito, o cscólio de Délio Maranhão, quanto discorria sobre o interesse contratual negativo no Dircito do Trabalho"2: "Assim é que, se os entendimentos preliminares chegaram a $u m$ ponto que faça prever a conclusão do contrato e uma das partes os rompe sem um motivo justo e razoável (culpa in contrahendo), a outra terá o direito ao ressarcimento do dano causado por esse

19. "O contrato prelimina; exceto quanto à forma, deve conter todos os requisitos essenciais ao comlrato a ser celebrado $"$. No contrato de emprego, são requisitos essenciais a função, o salário, o regime jurídico e - discute-se - a jornada.

20. Tratado de Direito Judicicirion do Trabalho, 2a ed., São Paulo, LTr, 1985, p.233.

21. Arnaldo Süssekind, Délio Maranhão, Segadas Vianna, João de Lima Teixeira Filho, Instituições de Direito do Trabalho, vol. I, 16a ed., São Paulo, LTr, 1997, pp.247-248. "In verbis": "Consideramos perfeitamente cabivel uma as̆où desta natureza na Justiça do Trabalho, em face do art. II 4 da Constituiģäo, que fala em 'outras controvérsias decorrentes da relasão de trabalho' Dir-se-á que essa relação não) chegou a se completar. mas o dano se apura, na hipótese, em fimsăo de sua previsivel formasăo e a culpa ocome na fase preliminar de am comtralo de trabalho [culpa in contrahendo]: a controvéssia se origina, pois. de ama relas̆āo de trabalho, embora no nascedouro". Contra, João Orestes Dalazen (Competência Material Traballhisı, São Paulo, LTr, 1994, pp. 105-106) e Antônio Lamarca (O Livro da Compelência, Sĩo Paulo, Revista dos Tribunais, 1979, p.118).

22. Ilem, p.247. 
rompimento (interesse contratual negativo), quando possa provar que, confiando na previsível conclusão do contrato, fez despesas em virtude de tais entendimentos [danos cmergentes], ou deixou de aceitar outra oferta tanto ou mais vantajosa [lucros cessantes]"

O tema cm discussão converge, ainda, para a questão dos limites da autonomia privada nos pré-contratos de traballho, sob o pálio do princípio da dignidade humana (especialmente no que concerne à tutela jurídica da intimidade) e à luz do disposto no art. 421 do NCC. O pensamento jurídico universal tende a resguardar a privacidade $\mathrm{c}$ a intimidade dos indivíduos no bojo dos contratos c, com mesma razão, lambém nas relações pré-contratuais. Assim, p. ex., entende-se que os contratos de trabalho $\mathrm{cm}$ geral não se admitem as revistas íntimas de rotina, senão em caráler excepcional (quando o empregador tem lundadas razões para crer na improbidade do empregado) ou periodicamente, se o exigir a atividade econômica, por sua especificidade (e.g., empresas de guarda e administração de bens e valores). No mesmo sentido, privilegiando o direito à intimidade (mas agora no campo do pré-contrato de trabalho), a doutrina espanhola chega ao ponto de censurar - talvez com certo exagero - a própria investigação grafológica a que se submete o futuro empregado. Grafologia, nessa acepção, é o método de aferição de tendências e traços de personalidade por meio do cxame dos elementos gráficos recorrentes na caligrafia do examinando; normalmentc, ć com essa intenção $\mathfrak{x}$ descobrir aspectos da personalidade do candidato $\mathfrak{x}$ que as cmpresas compelem entrevistados a redigir suas solicitações de trabalho de forma manuscrita. Sobre isso, aliás, releva transcrever a notícia de Alice Monteiro de Barros ${ }^{23}$ : "Sustenta a doutrina espanhola que esse critério [avaliação grafológica] comporta uIm conhecimento profundo da personalidade e, contrariamente a outros testes, não torna possivel isolar individualmente certos traços, sem conhecer o restante, logo, não permite analisar apenas os que estão em conexão direta com o cargo a ser ocupado; a grafologia implica intromissão ilegítima e por isso mesmo não poderá ser utilizada como critério de seleção, nem mesmo se precedida da aquiescência do candidato. 'É que mesmo a autonomia da vontade deverá operar nos limites da lei, da moral e da ordem pública. E não há dívida de que prestar un consentimento para realizar uma prova grafológica significa bem mais que um parcial desprendimento de alguma das faculdades do direito à intimidade; é renunciar a liberdade do íntimo, o que resulta contrário à moral e à ordem pública"”

23. Cfr. Alice Monteiro de Barros, Proteçāo à Intimidade do Empregado, São Paulo, LTr, 1997, p. 62 (citando textualınente José Luis Goñi Sein, na obra "El respeto a la esfera privada del trabajador; estudio sobre los limites del poder de control empresarial" a g.n.). 
O problema está a merecer, no Brasil, maiores debates em sede doutrinária. Na jurisprudência, pouco ou nada se vê a esse propósito, mesmo porque a avaliação) gralobógica ainda não foi scriamente incorporada pela comunidade cientílica nacional. De todo modo, a casuística inexpressiva indica que, até o momento, o traballhador brasilciro mediano não $\mathrm{tem}$ reconhecido, nos testes gralológicos, qualquer sorke de violação aos scus dircitos constitucionais de privacidade e intimidade. Mas é curial reconhecer, na mesma ensancha, que o excrcício da aulonomia privada c da liberdade de contratar (e de pré-contratar) não pode desbordar dos limites da dignidade humana, com lodos os seus desdobramentos, segundo os padrões culturais vigentes no país.

Ainda no marco da dignidade humana, e finalizando o exame do précontrato de trabalho à luz do CC de 2002, convém observar que os arts. 464 e 467 do NCC são inaplicáveis às relações de cmprego.

O primeiro é inaplicável, porque a adjudicaf̧ão compulsória do contrato de trabalho, se imposta ao trabalhador, violaria lirontalmente a liberdade constitucional do trabalho e, por consequiência, o próprio princípio da dignidade humana (por ser o trabalho, afinal, uma extensão/projeção da personalidade do trabalhador, indissociável da pessoa espiritual); se imposta ao cmpregador, por outro lado, representaria uma constrição indevida ao direito de propriedade (tanto mais no Brasil, em que o empregador detém o direito potestativo de dispensar seu cmpregado) e uma violação oblíqua ao princípio da livre iniciativa, além de engendrar situações insustentáveis no imo da unidade produtiva.

O segundo (art. 467 do NCC) trata do contrato com pessoa a declarar, sendo inaplicável às relações de emprego $\mathrm{cm}$ vista do art. $3^{\circ}$, caput, da CLT: a modalidade não transige com o pressuposto da pessoalidade, ínsito à relação de cmprego. Tem aplicação, todavia, às relações de trabalho ("lato sensu") que não exigem pessoalidade, como no trabalho eventual.

Em relação ao art. 467, Edilton Meireles sustenta que "essa hipótese poderá ocorrer (...) quando o empregador, na conclusão do contrato, reserva-se na faculdade de indicar outra empresa que assumirá os direitos e obrigações decorrentes do contrato, especialmente se do mesmo grupo cconômico"24 Pensamos, porém, que a responsabilidade patrimonial do cmpregador ("Hoftung") é intransferível, de mancira que um pacto dessa natureza feriria a ordem pública, encontrando óbice no art. 421 do

24. Edilton Meireles, O Nowo Código Civil e o Direito do Traballo. São Paulo, LTr, 2002, p.92. 
NCC. Tenha-se em conta que a responsabilidade pessoal do empregador é inerente à natureza do contrato de trabalho, de modo que a cláusula de transferência é leonina c, por conseguinte, nula de pleno dircito, tanto mais quando se trata de contrato-formulário (supra, tópico 2.3). Aliás, na hipótese de grupo econômico (alvitrada por Meireles), a responsabilidade distribui-se solidariamente "ope legis" consoante art. $2^{\prime \prime}, \$ 2^{\circ}$, da CLT, que encerra norma de ordem pública, inaltcrável por convenção das partes (art. 2035, par. único, do NCC). Inlactível, cnlim, a cessão de dívida trabalhista (de uma cmpresa a outra), ante o princípio da proteção que rege as relações de cmprego (regra da condição mais benélica), sempre que essa cessão conligurar obstáculo à realização do crédito ac como de regra ocorre. Mas a recíproca, como se sabe, não ć verdadeira: a jurisprudência pátria tem admitido, no interesse do empregado, a cessão do crédito trabalhista ("não podendo, porém, ser operacionalizada no âmbito da Justiça do Trabalho, sendo como é unn negócio juridico entre empregado e terceiro, que não se coloca em qualquer dos pólos da relação processual traballhista" $x$ Provimento TST/ CGJT n. 06, de 19.02.2000).

Admitindo-se, lodavia, a cessão de débito c/ou o contrato com pessoa a declarar no âmbito das relações de emprego ax como quer Meircles $\mathfrak{x}$, convirá atentar para o teor do art. 470 do NCC (caso o empregador não aponte, desde logo, quem assume as obrigações trabalhistas): a nomeação e/ou cessão será ineficaz, se (a) não houver a indicação da pessoa cm tempo razoávcl; se (b) o nomeado ou cessionário se recusar a accitá-la; ou, ainda, se (c) a pessoa nomcada ou o cessionário era insolvente c o credor desconhecia essa situação no momento da indicação. Outra hipótese de incficácia dar-se-á quando a aceitação não se reveste da forma que as partes usaram para o contrato originário (assim, e.g., se o contrato de trabalho for firmado por instrumento público), ut art. 468, par. único, do NCC. Em todos esses casos, "fica sem efeito a cláusula de reserva de nomeação [ou a cláusula de cessão], mantendo-se no comrato as mesmas partes" 25

2.6. Resolução do contrato de trabalho por oncrosidade excessiva.

Para contratos de execução continuada (como é o contrato de trabalho) ou dilerida, o Código Civil, de 2002, cstabelece que "se a prestação de uma das partes se tornar excessivamente onerosa, com extrema vantagem para a outra, em virtude de acontecimentos extraordinários e imprevisíveis, poderá o devedor pedir a resolução

25. Nery Jr., op.cil., pp. 191-192. 
do contrato. Os efeitos da sentença que a decretar retroagirão à data da citação" O preceito operacionaliza a aplicaçũão da teoria da imprevisão aos contratos, reconhecendo uma cláusula "rebus sic stantibus" implícita c inerente a todo e qualquer contrato.

No Direito do Trabalho, essa norma civil poderá ter utilidade em contextos de hipcrinllação ou de desvalorização abrupta da moeda, quando a corrosão do poder de compra dos salários se tornar insuportável para o trabalhador, sem contrapartida razoável por parte do empregador. A hipólese poderá enscjar, sob tais circunstâncias, o ajuizamento de ação judicial postulando a resolução do contrato (diversa, portanto, da resilição), que se fará por iniciativa do empregado, "sem que com isso seja obrigado a dar aviso prévio" ${ }^{26}$ Legislação brasileira dos anos de chumbo prevê, aliás, ensejo semelhante para o cmpregador, facultando-lhe exereer judicialmente o dircito de reduzir salários, quando as despesas correspondentes comprometerem a continuidade da atividade cconômica (não-recepcionada pela CRFB/88, cm vista do que dispõe o seu art. 7" sobrc a irredutibilidade de salários $\mathrm{e}$ a via única de llexibilização negociada na instância sindical). É justo que, agora, se reconheça o direito reverso ao trabalhador brasileiro, por conta da nova legislação civil, de aplicação subsidiária às relações de emprego.

Os efeitos da resolução, segundo pensamos, não serão os mesmos da resiliç̧ão unilatcral do empregador ou da rescisão indireta (art. 483 da CLT), vez que (a) a iniciativa não coube ao cmpregador $\mathrm{c}$ (b) o fato não é, em tesc, imputável ao empregador (se o fosse, tratar-se-ia de rescisão indireta e não de resolução). Assim, pagam-se apenas os títulos proporcionais (férias $+1 / 3 \mathrm{c}$ décimo terceiro salário), sem desconto de aviso prévio (art. 487, \$2", da CLT) e com movimentação do FGTS (art. 20, I, da Lei n. 8.036/90 - força maior).

Outro emprego para essa norma - indiscutivelmente polêmico surgirá ao se evocá-la para reajustar cláusulas de terinos de conciliação lavrados na Justiça do Trabalho, dada a sua natureza jurídica contratual (negócio jurídico processual). Imagine-se, e.g., um acordo homologado com parcelas a perder de vista, sem indexação, surpreendido por aguda crise cambial, que faça disparar os índices de inflação. Admitir a tese da resolução significará reconhecer uma cláusula resolutiva tácita implícita a todo termo de conciliação, além da própria natureza "rebus sic stantibus" do termo lavrado, cujo eleito de coisa julgada dobrar-se-ia ante o contexto de oncrosidade excessiva (conquanto valha, no mais, "como decisão irrecorrivel", com caráler de lítulo executivo judicial: art. s 831, par. único, e 876, caput, da CLT). Não admiti-la significará, por outro lado, carrear ao trabalhador, no âmbito do seu litígio, o ônus integral 
pelo fracasso das políticas econômicas praticadas. Ante semelhante dilema, melhor será optar pela segurança jurrídica, preservando a lorça do julgado que recobre o negócio jurídico processual, a despeito da alteração abrupta c imprevisível da situação de fato.

Sempre que se reclama a resolução do contrato por oncrosidade excessiva, é dado ao réu oferecer a modificação equiitativa das condições do contrato, nos termos do art. 479 do NCC. Nos exemplos acima, caberia lazê-lo mediante proposta de cláusula de indexação monetária, compensando a corrosão inllacionária. Accita a proposta pela parte reclamante, extinguc-sc o lecito com julgamento de mérito (transação - art. 269, III, do CPC). Não accita, cabcrá ao juiz decidir, cm sentença, sc a modilicação proposta seria ou não eqüitativa. Em caso negativo, decretará a resolução do contrato, ditando os seus clcitos. Em caso positivo, prescrvarí o contrato de trabalho, prestigiando o princípio da continuidade $\mathrm{c}$ conlerindo lorça judicial à proposta do réu, para agregá-la ao contrato, com efcitos retroativos à cilação (exegese do art. 478, in fine, do NCC). Em face dessa derradcira possibilidade, ć lorçoso reconhecer, em toda ação de resolução contralual por oncrosidade excessiva, pediclo implícito de adequação eqüitativa das condições contraluais, sob pena de confrontar, sempre, os limites do art. 293 do CPC. Fosse de outro modo, estaria legalmente oportunizada a litigância de má-fé: o réu proporia modificações expressivas na contestação, scm qualquer compromisso sincero, apenas para ver a ação julgada improcedente.

A hipótesc do art. 480 do NCC é própria dos contratos unilaterais e/ou gratuitos (e.g., depósito, comodato etc.), não se aplicando ao Direito do Trabalho, em que os contratos são, por excelência, bilaterais e comutativos.

\subsection{Distrato c resilição.}

O art. 473 do NCC alude ao instituto do distrato. No Código Civil de 2002, cssa expressão é utilizada na acepção geral de dissolução do contrato. Não está empregada, portanto, com acepção cstrita, própria de "quando são as duas partes que querem paralisar os efeitos do contrato" hipótese cm que "celebram outro contrato para dissolver o que os vincula. Pelo contrarius consensus aniquilam o vínculo, impedindo que continue a produzir efeitos. a esse contrato extintivo denomina-se distrato ou distrate. Trata-se de forma on modo de dissolução, admissível no contrato de trabalho, que, entretanto, não é frequiente (...)" ${ }^{27}$ Mas é claro que essa figura cncontra

27. Orlando Gomes, Elson Gottschalk, Curso de Direito do Traballo, I4a ed., Rio de Janeiro, Forense, 1996, p. 357. 
amparo na própria sistemática da "lex nova" a sendo que, a tcor do art. 472 do NCC, o distrato deve ser leito pela mesma forma exigida para o contrato (clir. art. 1.093 do Código Civil de 1916).

Por outro lado, o Código Civil de 2002 consagra, no âmbito do Dircilo Civil, a expressão "resilição". que lora incorporada c difundida no mcio jurídico pelo Direito do Trabalho, para significar as hipóteses de denúncia vazia do contrato de trabalho (pelo empregador $\mathfrak{x}$ dispensa $\mathfrak{x}$ ou pelo empregado $\mathfrak{x}$ demissão "stricto sensu"). A referência está no art. 473 do NCC, entendendo-se ali, como resilição, a demíncia vazia do contrato por iniciativa de uma das partes (= unilateral). Adotou-se, portanto, a acepção talhada pelos juslaboralistas (c, menos signilicativamente, pelos juscivilistas que, para tanto, se abeberavam na doutrina estrangeira). A resilição opera efeitos mediante denúncia notificada à outra parte (art. 473, caput, do NCC), que nos contratos do trabalho tem disciplina própria (arts. 487 a 491 da CLT).

Se, dada a natureza do contrato, uma das partes houver feito investimentos consideráveis para a sua execução, a denúncia unilateral só produzirá eleitos depois de transcorrido o prazo compativel com a natureza e o vulto dos investimentos, nos tcrmos do art. 473, par. único, do NCC. Essa regra aplicar-se-ia ao Dircilo do Trabalho $\mathrm{cm}$ casos como o do cmpregado que "ingressa em curso de aperfeiçoamento, readaptaşão on treinamento, etc., buscando melhor preparo para exercício das tarefas exigidas pelo empregador: Vindo a ser despedido sem justa causa antes mesmo de poder recuperar o auto-investimento (...), poder-se-ia assegurar ao trabalhador a prorrogação do contrato por 'prazo compativel com a natureza e o vulto dos investimentos." $2 x$ O exemplo do autor é encontradiço no ramo de segurança privada (cursos de vigilantes). Meireles excmplifica, ainda, com o cmpregado que adquire veículo para ser contratado (e.g., motoboy), ou que realiza despesas de mudança $\mathrm{e}$ transporte para poder assumir cmprego cm local distante de sua residência, e logo é demitido. Sugere, enfim, que se aplique o mesmo princípio no caso de o cmpregador investir no cmpregado, financiando cursos (inclusive no exterior).

De nossa parte, cremos indevida qualquer prorrogação do contrato contra a vontade das partes, vez que poderia signilicar, para a generalidade dos empregados de "staff" odiosa restrição à liberdade de trabalho, estendendo-lhes por via oblíqua algo como o famigerado "passe" dos atletas de futebol, felizmente extinto. Essa ingerência da lei civil em matćria trabalhista violaria princípios constitucionais (da dignidade humana e da liberdade de trabalho, ut CF I", III, e 5", XIII, no caso do

28. Mcircles, op.cit., p.93. 
cmpregado; da livre iniciativa e da propricdade privada, $u t \mathrm{CF} 170$, caput e I, no caso do compregador).

III. Conclusão.

Das considerações até aqui registradas, podem-sc inferir, como ilações principais, as seguintes.

1. As normas de Dircito Civil informam as relações de trabalho em caráter subsidiário, o que pressupõe o atendimento de duas condições de aferição estritamente hermenêutica, a saber, a lacuna no sistema legal-trabalhista, e a compatibilidade entre a norma de Direito Civil e os princípios retores do Direito do Trabalho (sintetizados em quatro entidades: princípio da proteção, princípio da primazia da realidade, princípio da irrenunciabilidade e princípio da razoabilidade).

2. Há três cláusulas gerais do direito dos contratos que regulam a interação jurídica: a autonomia privada, o respeito à ordem pública e a função social do contrato. Também nos contratos de trabalho, a lunção social do contrato determina os limites da liberdade de contratar, no âmbito individual e coletivo. Trata-se de um marco positivo para a operacionalização do princípio da razoabilidade, entendendo-se como lunção social de todo contrato a de propiciar circulação de riqueza, enquanto as funções sociais especílicas do contrato de trabalho são as de distribuir riqueza (obstando, na ótica marxista, uma apropriação selvagem c desumana da mais-valia) c tutelar a dignidade humana.

3. Os princípios da probidade c da boa-lé (art. 422 do NCC) servem, no) Direito do Traballho, à lisscalização judicial do modo de execução dos contratos coletivos, lanto mais se vingar a polêmica reforma do art. 618 da CLT; scrvem também à lïscalização e solução de problemas cspecílicos de dircito individual do trabalho, como a questão da responsabilidade do futuro empregador pela promessa de contratar c/ou pelas cláusulas de pré-contrato de trabalho (princípio da boa-fé objetiva) e a questão da responsabilidade do empregador público pelos consectários de contrato de trabalho nulo (CF art. 37, \$2"), em casos de cooptação do trabalhador de boa-fé mediante contrato aparentemente válido e eficaz (princípio da aparência).

4. O excrécio da autonomia privada e da liberdade de contratar (e de pré-contratar) não pode desbordar dos limiles da dignidade humana, com todos os scus desdobramentos, segundo os padrões culturais vigentes no país.

5. Compete à Justiça do Trabalho processar e julgar os dissídios 
individuais entre trabalhadores $\mathrm{c}$ cmpregadores, $\mathrm{cm}$ ato (contrato de trabalho definitivo) ou polência (contrato preliminar de traballho). Essa competência estende-se às promessas de contrato de terceiro, na forma dos arts. 439-440 do NCC, se estiverem delineados todos os elementos essenciais que constituiriam o contrato de trabalho delinitivo.

6. No marco do princípio da dignidade humana, é mister reputar inaplicáveis às relações de emprego os arts. 464 e 467 do NCC.

7. O Código Civil de 2002 prevê ação judicial para resolução do contrato por excessiva onerosidade. O preceito ganha relevância, no Direito do Trabalho, cm. contextos de hiperinflação ou de desvalorização abrupta da moeda, quando a corrosão do poder de compra dos salários se tornar insuportável para o trabalhador, sem contrapartida razoável por parte do empregador. Admite-se, a teor da "lex nova" que o réu (empregador) ofereça a modificação eqüitativa das condições do contrato (como, c.g., cláusula de indexação monetária).

8. É dever histórico dos operadores do Dircito do Trabalho, e especialmente dos juízes do Trabalho, implementar a aplicação subsidiária das normas compatíveis do Código Civil de 2002, naquilo que for omissa a legislação trabalhista tendo cm conta, sempre, a justiça material e o disposto no art. 5" da LICC, mas com vistas à modernização oblíqua do vetusto arcabouço legislativo que regula, no Brasil, as relações de trabalho.

São Paulo, maio de 2003. 
IV. Bibliografia.

ALBUQUERQUE, Bruno Fernandes. “A última reforma do Código de Processo Civil e a sua repercussão no processo do trabalho" In: Revista LTr 66-03/300-309.

BARROS, Alice Monteiro de. Proteção à Intimidade do Empregado. São Paulo: LTr, 1997.

BATALHA, Wilson de Souza Campos. Tratado de Direito Judiciário do Trabalho. $2^{a}$ ed. São Paulo: LTr, 1985.

BENJAMIN, Antonio Herman V. "Função Ambiental". In: Dano Ambiental Prevenção, Reparação e Repressão. São Paulo: Revista dos Tribunais, 1993.

DALAZEN, João Orestes. Competência Material Trabalhista. São Paulo: LTr, 1994.

GOMES, Orlando. GOTTSCHALK, Élson. Curso de Direito do Trabalho. 14: cd. Rio de Janeiro: Forense, 1996.

LAMARCA, Antônio. O Livro da Competência. São Paulo: Revista dos Tribunais, 1979.

MEIRELES, Edilton. O Novo Código Civil e o Direito do Trabalho. São Paulo: LTr, 2002.

NASCIMENTO, Amauri Mascaro. Conferência de Abertura. In: 10" Congresso Brasileiro de Direito do Trabalho. São Paulo: LTr, 16.04.2002.

NERY JUNIOR, Nelson. ANDRADE NERY, Rosa Maria de. Novo Código Civil e Legislação Extravagante Anotados. São Paulo: Revista dos Tribunais, 2002.

OLIVEIRA SILVA, José Antonio Ribeiro de. "A alteração nos arts. 475 e 515 do CPC e sua aplicação no processo do trabalho" In: Revista LTr 66-12/1461-1468.

RÁO, Vicente. Ato Jurídico. 4a ed. São Paulo: Revista dos Tribunais, 1997.

RODRIGUEZ, Américo Plá. Princípios de Direito do Trabalho. Trad. Wagner Giglio. São Paulo: LTr, 1996.

RUSSOMANO, Mozart Victor. Princípios Gerais de Direito Sindical. Rio de Janeiro: Forense, 1995.

SÜSSEKIND, Arnaldo. MARANHÃO, Délio. VIANNA, Segadas. TEIXEIRA FILHO, João de Lima. Instituições de Direito do Trabalho. 16" ed. São Paulo: LTr, 1997. v. I.

TEIXEIRA FILHO, Manoel Antonio. "Código de Processo Civil a alterações: breves comentários às Leis n. I0.352 e 10.358/200I" In: Revista LTr 66-03/263-276. 